\title{
Artikel Penelitian/Article Reviu \\ Implementasi Model Pembelajaran Think Pair Share untuk Meningkatkan Hasil Belajar Siswa
}

\author{
Petrus Seingo Bobo \\ Program Studi Pendidikan Matematika, STKIP Weetebula, Jl. Mananga Aba, Sumba \\ Barat Daya-NTT, Indonesia \\ Email: petrusseingobobo@gmail.com
}

\begin{tabular}{|c|c|}
\hline ARTICLE INFO & ABSTRACT \\
\hline $\begin{array}{l}\text { Article history } \\
\text { Received: July } 2018 \\
\text { Revised: August } 2018 \\
\text { Accepted: October } 2018 \\
\text { Published: December } 2018 \\
\\
\text { Keywords } \\
\text { Think Pair Share (TPS) } \\
\text { Learning model; } \\
\text { Learning outcomes }\end{array}$ & $\begin{array}{l}\text { [Title: The Implementation of Think Pair Share Learning Models to Improve } \\
\text { Student Learning Outcomes]. The purpose of this study was to improve the learning } \\
\text { outcomes of Class VII Students of SMP Negeri } 1 \text { Loura, the subject of Linear One } \\
\text { Variable Equation through the Think Pair Share (TPS) Learning model. This type of } \\
\text { research is classroom action research that is reflective by taking certain actions in order } \\
\text { to improve and enhance classroom learning practices in practice and professionally. The } \\
\text { subjects of the research were VII grade students of SMP Negeri } 1 \text { Loura for the } \\
\text { Academic Year 2017/2018, amounting to } 43 \text { people. The data collection tools used were: } \\
\text { tests and observations. Data analysis techniques were obtained from the teacher, } \\
\text { student activity data and test results. The indicator of the success of this class action } \\
\text { research is said to be successful if it reaches classical completeness of } 75 \% \text { with the } \\
\text { Minimum completeness Criteria (KKM) 70. The results obtained, in the first cycle test } \\
\text { students who completed reached } 62.79 \% \text { and incomplete reached } 37.21 \% \text {. While the } \\
\text { second cycle of students who completed tests reached } 81.39 \% \text { and } 18.61 \% \text { of incomplete } \\
\text { completed. And the average results of observations in the first cycle for the first meeting } \\
\text { is } 2.25 \text { and for the second meeting is 2.63, and the results of observations in the second } \\
\text { cycle for the first meeting is } 3.00 \text { and for the second meeting is } 3.25 \text {. Based on the results } \\
\text { of the study it can be concluded that the implementation of the TPS learning model can } \\
\text { improve student learning outcomes. }\end{array}$ \\
\hline
\end{tabular}

\begin{tabular}{|c|c|}
\hline INFO ARTIKEL & ABSTRAK \\
\hline Sejarah Artikel & Tujuan penelitian ini adalah untuk meningkatkan hasil belajar Siswa Kelas VII \\
\hline Dikirim: Juli 2018 & SMP Negeri 1 Loura Pokok Bahasan Persamaan Linear Satu Variabel melalui \\
\hline Direvisi: Agustus 2018 & model Pembelajaran Think Pair Share. Jenis penelitian adalah penelitian \\
\hline Diterima: Oktober 2018 & tindakan kelas yang bersifat reflektif dengan melakukan tindakan-tindakan \\
\hline Dipublikasi: Desember & tertentu agar dapat memperbaiki dan meningkatkan praktik-praktik \\
\hline 2018 & $\begin{array}{l}\text { pembelajaran di kelas secara praktik dan profesional. Subjek penelitian adalah } \\
\text { siswa kelas VII SMP Negeri } 1 \text { Loura Tahun Ajaran 2017/2018 yang berjumlah }\end{array}$ \\
\hline Kata kunci & 43 orang.Alat pengumpul data yang digunakan: tes dan observasi. Teknik \\
\hline Model Pembelajaran & analisis data diperoleh dari data aktivitas guru, siswa dan hasil tes. Indikator \\
\hline Think Pair Share; & keberhasilan penelitian tindakan kelas ini dikatakan berhasil jika mencapai \\
\hline Hasil belajar & $\begin{array}{l}\text { ketuntasan klasikal } 75 \% \text { dengan KKM } 70 \text {. Hasil penelitian yang diperoleh, } \\
\text { pada tes siklus I siswa yang tuntas mencapai } 62.79 \% \text { dan tidak tuntas mencapai } \\
37.21 \% \text {. Sementara tes siklus II siswa yang tuntas mencapai } 81.39 \% \text { dan yang } \\
\text { tidak tuntas mencapai } 18.61 \% \text {. Dan hasil rata-rata observasi pada siklus I untuk } \\
\text { pertemuan I yaitu } 2.25 \text { dan untuk pertemuan II yaitu } 2.63 \text {, dan hasil observasi } \\
\text { pada siklus II untuk pertemuan I yaitu } 3.00 \text { dan untuk pertemuan II yaitu } 3.25 \text {. } \\
\text { Berdasarkan hasil penelitian dapat disimpulkan bahwa penerapan mode } \\
\text { pembelajaran TPS dapat meningkatkan hasil belajar siswa. }\end{array}$ \\
\hline
\end{tabular}


How to Cite this Article? Bobo, P., S. (2018). Implementasi Model Pembelajaran Think Pair Share untuk Meningkatkan Hasil Belajar Siswa. Jurnal Penelitian dan Pengkajian Ilmu Pendidikan: e-Saintika, 2(1), 49-54.

\section{PENDAHULUAN}

Persamaan Linear Satu Variabel merupakan salah satu materi yang diajarkan di kelas VII semester II. Persaamaan Linear Satu Variabel banyak diterapkan baik dalam materi matematika lainnya ataupun pada masalah dalam kehidupan seharihari (Dewi, 2008). Oleh karena itu, penerapan model pembelajaran yang tepat sangat diperlukan sehingga siswa dapat menguasai materi dengan baik dan mampu menerapkan dalam masalah-masalah yang berkaitan dengan Persamaan Linear Satu Variabel.

Berdasarkan hasil observasi peneliti saat melaksanakan Praktik Pengalaman Lapangan (PPL) di SMP N 1 Loura Kecamatan Loura, Kabupaten Sumba Barat Daya, telah diperoleh data bahwa hasil belajar matematika siswa kelas VII, untuk materi persamaan linear satu variabel masih tergolong rendah. Materi persamaan linear satu variable ini, banyak siswa yang belum bisa menentukan cara menyelesaikan suatu persamaan linear satu variabel. Hal ini dapat dilihat dari nilai MID siswa kelas VII tahun 2016/2017 pada Tabel 1 sebagai berikut.

Tabel 1. Nilai MID Semester II Matematika

\begin{tabular}{lllll}
\hline \multirow{2}{*}{ Kelas } & \multicolumn{2}{l}{ Jumlah Siswa yang Mencapai KKM } & Ketuntasan Klasikal & $\begin{array}{l}\text { Jumlah } \\
\text { Siswa }\end{array}$ \\
\cline { 2 - 3 } & $<70$ (tidak tuntas) & $\geq 70$ (tuntas) & & 35 \\
\hline VII A & 20 & 15 & $42 \%$ & 33 \\
VII B & 15 & 18 & $54 \%$ & 40 \\
VII C & 22 & 18 & $45 \%$ & S
\end{tabular}

Sumber: Dokumentasi Nilai MID Semester Guru Mata Pelajaran Matematika SMP N 1 Loura Tahun Ajaran 2016/2017

Berdasarkan Tabel 1 di atas nilai ulangan MID semester II kelas VII Tahun Ajaran 2016/2017 belum mencapai ketuntasan klasikal. Sementara target ketuntasan klasikal adalah $75 \%$ dengan siswa mencapai nilai lebih besar dari atau sama dengan 70. Bahkan untuk Kelas VIIA dan VIIC dibawah 50 persen untuk ketuntasannya.

Hasil wawancara dengan guru mata pelajaran matematika SMPN 1 Loura, rendahnya hasil belajar tersebut disebabkan karena siswa cenderung pasif saat pembelajaran. Saat guru memberi penjelasan, siswa-siswi ribut di belakang dengan urusannya sendiri. Siswa berdiskusi dengan teman-temannya membahas hal di luar materi pembelajaran. Dampaknya ketika diberikan latihan soal, mereka kebingungan untuk menyelesaikannya.

Berdasarkan paparan-paparan di atas dapat disimpulkan bahwa penyebab rendahnya hasil belajar adalah model pembelajaran yang digunakan oleh guru dalam menyajikan materi matematika kurang bervariatif, sehingga menimbulkan pembelajaran yang monoton. Oleh karena itu, guru harus mampu melibatkan siswa secara aktif dengan model-model pembelajaran yang mampu menghidupkan kelas. Salah satu metode yang dapat digunakan peneliti untuk memenuhi kebutuhan tersebut adalah dengan menerapkan model Think Pair Share (TPS). 
Menurut Widodo (2009), TPS dapat memperbaiki rasa percaya diri dan semua siswa diberi kesempatan untuk berpartisipasi dalam kelas khususnya lagi pada mata pelajaran matematika. Siswa yang tadinya pasif dapat terpacu untuk ikut aktif dalam pembelajaran, sehingga pembelajaran juga tidak terpusat pada guru. Berdasarkan uraian di atas, penelitian tindakan kelas dengan judul, "Implementasi Model Pembelajaran Think Pair Share untuk Meningkatkan Hasil Belajar Siswa" perlu dilakukan. Penelitian ini bertujuan untuk meningkatkan hasil belajar siswa kelas VII SMP Negeri 1 Loura pokok bahasan persamaan linear satu variabel melalui model pembelajaran Think Pair Share.

\section{METODE}

Jenis penelitian ini adalah penelitian tindakan kelas, Penelitian ini dilakukan di SMP Negeri 1 Loura Kecamatan Loura Kabupaten Sumba Barat Daya pada semester genap tahun 2017/2018 dengan rincian 43 orang siswa yang terdiri dari 26 laki dan 17 perempuan. Prosedur penelitian tindakan kelas ini terdiri dari dua siklus dengan tiap siklus dilaksanakan sesuai dengan perubahan yang ingin dicapai pada faktor-faktor yang diselidiki. Setiap siklus dalam penelitian ini mengikuti prosedur penelitian berikut (1) perencanaan, (2) pelaksanaan tindakan, (3) observasi dan evaluasi, (4) refleksi. Sumber data adalah siswa kelas VII SMPN 1 Loura dengan jenis data yaitu data kuantitatif yakni diperoleh dari tes prestasi belajar dan data kualitatif diperoleh dari lembar observasi.

Teknik pengambilan data mengenai proses pelaksanaan model pembelajaran TPS di ambil dengan menggunakan lembar observasi, data mengenai prestasi belajar matematika diambil dengan menggunakan tes. Teknik Analisis data yaitu dengan menganalisis aktivitas guru yang dilakukan melalui observasi langsung oleh observer (pengamat), data mengenai aktivitas guru ini digunakan sebagai pedoman guru untuk memperbaiki pelaksanaan pembelajaran pada pertemuan berikutnya. Data observasi aktivitas siswa dalam mengikuti pembelajaran dengan menggunakan model TPS dinyatakan dalam skor rata-rata aktivitas siswa dalam mengikuti pembelajaran dikatakan efektif jika skor dari semua aspek yang dinilai berada pada kategori baik. Data hasil tes setiap siklus dianalisis dengan menggunakan rumus:

Keterangan:

$$
\mathrm{KB}=\frac{X}{Z} \times 100 \%
$$

$\mathrm{KB}=$ Ketuntasan belajar

$\mathrm{x}=$ Banyaknya siswa yang memperoleh nilai $\geq 70$

$\mathrm{z}=$ Banyaknya Siswa

Setelah data hasil tes tersebut dianalisis, langkah selanjutnya adalah menyajikan dalam bentuk tabel sehingga memudahkan dalam penarikan kesimpulan. Setelah data tersebut disajikan, kemudian langkah berikutnya adalah menarik kesimpulan terhadap hasil penafsiran dan evaluasi. Kegiatan ini mencakup pencarian makna data dan memberi penjelasan. Selanjutnya verifikasi, yaitu menguji kebenaran, kekokohan dan mencocokkan makna-makna yang muncul dari data. 


\section{HASIL DAN PEMBAHASAN}

Hasil penelitian pada siklus I yang dilakukan pada siswa kelas VII SMP Negeri 1 Loura adalah sebagai berikut: banyaknya siswa yang memperoleh nilai rendah pada saat test dilakukan yaitu, dari siswa kelas VII B yang berjumlah 43 orang hanya 27 orang siswa saja yang mendapatkan nilai lebih dari standar ketuntasan maksimal. Sedangkan sisanya yang 16 orang siswa memperoleh nilai di bawah standar ketuntasan maksimal. Proses pembelajaran pada siklus belajar, bimbingan dan perhatian yang khusus diberikan ketika proses belajar mengajar berlangsung, di samping itu juga guru melakukan upaya deteksi kendala-kendala yang dihadapi atau penyebab-penyebab lain yang dialami oleh 16 siswa tersebut.

Berdasarkan refleksi yang dilakukan antara peneliti dan guru mata pelajaran Matematika pada siklus I ditemukan beberapa permasalahan yang menjadi kendala dalam hasil belajar Matematika sebagai berikut.

1. Kondisi kemampuan akademik siswa dalam menerima pelajaran sangat heterogen sehingga tidak jarang menjadi permasalahan bagi guru dalam memberikan pelajaran.

2. Rendahnya minat dan rasa ingin tahu siswa dalam mempelajari materi matematika, hal ini disebabkan karena siswa belum terbiasa dengan penerapan model TPS.

Akibat dari kedua masalah di atas maka penguasaan siswa terhadap materi pelajaran Matematika kurang dioptimalkan. Sementara hasil penelitian pada siklus II banyaknya siswa yang memperoleh nilai lebih dari standar ketuntasan maksimal yaitu 35 orang siswa dan yang memperoleh nilai kurang dari 70 yaitu hanya 8 orang siswa saja. Ini berarti bahwa penggunaan model pembelajaran yang diterapkan pada saat kegiatan pembelajaran berlangsung sangat membantu guna meningkatkan hasil belajar siswa kelas VII SMP Negeri 1 Loura.

Berdasarkan hasil penelitian model pembelajaran TPS yang diterapkan pada siswa kelas VII SMP Negeri 1 Loura khususnya pada mata pelajaran Matematika tentang Persamaan Linear Satu Variabel berdampak positif pada hasil belajar siswa, yang meliputi tes dan observasi.

Hasil penelitian menunjukkan data hasil belajar siswa dalam pelaksanaan model pembelajaran TPS yang dilakukan pada siklus II mengalami peningkatan. Keterlibatan dan keaktifan siswa selama proses pembelajaran menunjukkan bahwa motivasi siswa untuk belajar meningkat. Hasil penelitian menunjukkan bahwa keterlibatan siswa selama proses pembelajaran berlangsung berdampak positif terhadap hasil belajar siswa. Dengan kata lain bahwa tercapainya ketuntasan belajar siswa karena siswa memiliki sikap yang baik dan minat yang tinggi untuk belajar sehingga dengan mudah dapat memahami materi yang diajarkan.

Hasil tes pada siklus I sebesar 62.79 \% siswa yang tuntas, sedangkan pada siklus II mengalami peningkatan dengan ketuntasan $81.39 \%$, sehinga dapat dikatakan bahwa ada peningkatan hasil belajar siswa dari siklus I sampai siklus II.

Hasil penelitian menunjukkan bahwa model pembelajaran TPS dapat memperbaiki dan merubah sikap siswa selama proses pembelajaran di kelas. Jika pada awalnya siswa senantiasa diam, hanya mendengarkan dan mencatat apa yang disampaikan oleh guru, ribut dengan urusan sendiri. Setelah diberi tindakan yakni dengan menerapkan model pembelajaran TPS di dalam kelas siswa sudah aktif. 
Hasil yang diperoleh dapat kita lihat dari peningkatan hasil belajar siswa pada siklus I dan siklus II. Hal ini dikarenakan kelebihan dengan menggunakan model pembelajaran TPS tingkat keaktifan siswa dalam belajar meningkat, di mana siswa dituntut untuk berfikir secara individu kemudian berdiskusi dengan temannya untuk saling bertukar pikiran maupun bertukar informasi pengetahuan masingmasing. Kemudian siswa dituntut untuk berani mempresentasikan hasil pemikiran dan diskusinya didepan kelas, bagi siswa yang lain agar berani menyampaikan pendapatnya. Jadi pengetahuan yang di dapat oleh siswa tidak hanya berasal dari guru, akan tetapi dari contoh kongkrit dan juga pengalaman masing-masing individu. Ini sesuai dengan teori Anita Lie (2004) yang menyatakan bahwa TPS adalah salah satu metode pembelajaran yang memberi kesempatan pada siswa untuk bekerja sendiri serta bekerja sama dengan orang lain.

\section{KESIMPULAN}

Berdasarkan hasil penelitian dapat disimpulkan bahwa penerapan model pembelajaran TPS dapat meningkatkan hasil belajar siswa. Hal ini ditunjukan dengan adanya peningkatan persentase ketuntasan belajar siswa secara klasikal pada tiap-tiap siklus dimana pada siklus I sebesar $62.79 \%$ sedangkan pada siklus II meningkat menjadi $81.39 \%$. Begitu juga dengan aktivitas belajar siswa yang ditunjukkan dengan hasil observasi aktivitas belajarnya, dimana pada siklus I pertemuan pertama diperoleh skor rata-rata sebesar 2.25 dan pertemuan kedua 2.63 dengan kategori "Baik" sedangkan siklus II pertemuan pertama sebesar 3.00 dan pertemuan kedua 3.25 dengan kategori "sangat Baik".

\section{SARAN}

Guru disarankan untuk lebih kreatif lagi dalam mengelola metode agar siswa dapat lebih aktif dalam mengikuti pembelajaran, karena dengan menggunakan metode yang kreatif seperti metode TPS sudah terbukti dapat meningkatkan hasil belajar siswa. Siswa hendaknya bersungguh-sungguh memperhatikan penjelasan dari guru, agar selama proses pembelajaran terjadi suasana yang kondusif dan hasilnya bisa seperti yang diharapkan.

\section{DAFTAR PUSTAKA}

Dewi, N., T. (2008). Matematika BSE untuk SMP / MTS kelas VII. Jakarta: Kawan Pustaka.

Gufron, M. N, \& Risnawati. (2010). Gaya Belajar. Yogyakarta: Pustaka Pelajar.

Lie, A. (2004). Cooperative Learning. Jakarta: Grasindo.

Muslich, M. (2013). Melaksanakan PTK ITU MUDAH. Jakarta: PT Bumi Askara Rusman. (2012). Belajar dan Pembelajaran Berbasis Komputer. Bandung: CV Alfabeta. Sudirman. (2007). Matematika untuk SMP / MTS kelas VII. Jakarta: PT Bumi Askara Sujito, S. (2010). Cepat Menyelesaikan Soal Matematika. Jakarta: kawanPustaka Suprijono, A. (2009). Cooperative Learning: Teori dan Aplikasi PAIKEM. Yogyakarta: Pustaka Pelajar

Undang- undang RI Nomor 20 Tahun 2003 Tentang Sistem Pendidikan Nasional. Undang-Undang RI Nomor 14 Tahun 2005 Tentang Guru dan Dosen. 
Widodo, R. (2009). Model Pembelajaran Think Pair and Share (Frank Liman, 1985). Diakses 27 Oktober 2011, dari www wordpress.com:http:/ / susilofi.wordpres.com.

Witono, A. H. (2013). Belajar dan Pembelajaran. Mataram NTB. 